\title{
Tetanic Cataract
}

National Cancer Institute

\section{Source}

National Cancer Institute. Tetanic Cataract. NCI Thesaurus. Code C35068.

A cataract resulting from hypocalcemia. 